\title{
IMPLEMENTASI KURIKULUM 2013 MATA PELAJARAN AKIDAH AKHLAK DALAM MEMBINA AKHLAK SISWA DI MTs. N KEDIRI LOMBOK BARAT
}

\author{
Fawaz, Azra'i \\ STIT DARUSSALIMIN NW PRAYA LOMBOK TENGAH NTB \\ fawazbismillah@gmail.com \\ azrai354@gmail.com
}

\begin{abstract}
Abstrak
Implemetasi Kurikulum 2013 pada mata pelajaran akidah akhlak dalam membina akhlak siswa dan mengetahui proses pelaksanaan pembinaan akhlak serta mengetahui kendala dan solusi dalam pembinaan akhlak di Madrasah Tsanawiyah Negeri (MTs.N) Kediri Lombok Barat. Proses pembelajaran akidah akhlak di MTs.N Kediri menggunakan pendekatan saintifik dengan metode bervariasi dan mengunakan penilain autentik. Bentuk pembinaan akhlak dilakukan dengan pembinaan di dalam kelas dan di luar kelas. Dalam pelaksanaan terdapat kendala yang dihadapi guru seperti kondisi personal siswa dan terbatasnya waktu dalam membina siswa. Adapun upaya yang dilakukan adalah melakukan kerjasama pihak sekolah dengan wali murid dalam pembinaan akhlak. Kurikulum, bukan kata yang asing dalam dunia pendidikan. Pendidikan tidak lepas dari istilah ini, karena Kurikulum adalah salah satu komponen dari pendidikan. Dengan adanya Kurikulum pendidikan akan berjalan secara terstruktur dan sistematis demi tercapai tujuan pembelajaran yang diinginkan. Sejalan dengan kemajuan ilmu pengetahuan dan teknologi, pengembangan Kurikulum menjadi sangat penting.
\end{abstract}

Kata Kunci: Kurikulum 2013, Akidah Akhlak

\section{PENDAHULUAN}

1. Implementasi Tinjauan tentang Kurikulum 2013

a. Pengertian Kurikulum 2013

Istilah Kurikulum berasal dari kata courier yang berarti berlari, Kurikulum berarti suatu jarak yang harus ditempuh oleh seorang pelari dari garis start sampai dengan garis finish untuk memperoleh medali atau penghargaan. Jarak yang harus ditempuh tersebut kemudian diubah menjadi program sekolah dan semua orang yang 
terlibat di dalamnya. ${ }^{87}$ Dalam bahasa Arab, kurikulum dikenal dengan sebutan manhaj yang berarti jalan terang yang dilalui oleh manusia pada berbagai bidang kehidupanya. Ketika dikaitkan dengan dunia pendidikan, maka manhaj dimaknai sebagai jalan terang yang dilalui pendidik ${ }^{88}$.

Kurikulum adalah model yang diacu oleh pendidikan dalam upaya membentuk citra sekolah dengan mewujutkan tujuan pendidikan yang di sepakati. ${ }^{89}$

Sementara dalam pengertian lain menurut para ahli seperti Oemar Hamalik menyatakan Kurikulum adalah program pendidikan yang disediakan oleh lembaga pendidikan (sekolah) bagi peserta didik ${ }^{90}$.

Kurikulum 2013 merupakan pengembangan dari kurikulum tingkat satuan pendidikan (KTSP), dalam Kurikulum 2013 yang menjadi titik tekan adalah adanya peningkatan dan keseimbangan soft skills dan hard skills yang meliputi aspek kopetensi sikap, keerampilan dan pengetahuan. Sehingga dapat dipahami Kurikulum 2013 adalah sebuah kurikulum yang dikembangakan untuk meningkatkan dan menyeimbangkan kemampuan soft skills dan hard skills. ${ }^{91}$

Dari paparan diatas, dapat dipahami implementasi kurikulum merupakan rangkaian kegiatan, aktivitas dan program yang berkaitan dengan proses pembelajaran yang telah dituangkan dalam buku kurikulum. Adapun dalam konteks Kurikulum 2013 E Mulyasa menjelaskan bahwa implementasi kurikulum merupakan aktualisasi kurikulum dalam pembelajaran dan pembentukan kopetensi serta karakter peserta didik. ${ }^{92}$

Pendidikan karakter tidak hanya mengajarkan mana yang benar dan mana yang salah kepada anak, tetapi lebih dari itu pendidikan karakter menanamkan kebiasaan tentang yang baik sehingga peserta didik paham, mampu merasakan, dan mau melakukan yang baik.

Dalam kurikulum 2013 dituntut untuk dapat merubah peserta didik ke arah yang lebih baik. Oleh karena itu, Kementerian Pendidikan Nasional telah merumuskan 18

*Penulis merupakan Dosen Tetap pada Perguruan Tinggi Di Lingkungan STIT Darussalimin NW Praya NTB Sejak 2014-Sekarang

1 Zainal Arifin, Konsep dan Model Pengembangan Kurikulum (Bandung: Remaja Rosdakarya, 2011), 200.

2 H.M. Taofik, Kreativitas Jalan Baru Pendidikan Islam, (Mataram: LEPPIMV IAIN Mataram, 2012),137.

${ }^{3}$ Hassan Basri, Filsafat Pendidikan (Bandung: CV Pustaka Setia, 2014), 128.

${ }^{4}$ Zainal Arifin, Pengembangan Manajmen Mutu Kurikulum Pendidikan Islam (Jogjakarta: Diva Press, 2012), 37.

${ }^{5}$ Fadilah, Implementasi Kurikulum 2013 dalam Pembelajaran SD/MI, SMP/MTS\&SMA/MA (Yogyakarta: Ar-Ruzz Media, 2014 ), 16.

${ }^{6}$ Mulyasa, Impelemetasi Kurikulum 2013 (Bandung: Rosdakarya, 2013), 176. 
Nilai Karakter yakni : Religius, jujur, toletansi, disiplin, kerjakeras, kreatif, mandiri, demokratis, rasa ingin tahu, semangat kebangsaan, cinta tanah air, menghargai prestasi, bersahabat/komunikatif, cinta damai, gemar membaca, peduli lingkungan, peduli sosial dan tanggung jawab. ${ }^{93}$

Dari sekian banyak unsur sumber daya pendidikan, implementasi kurikulum merupakan salah satu unsur yang memberikan kontribusi signifikan untuk mewujudkan proses berkembangnya potensi peserta didik. Jadi tidak dapat disangkal lagi bahwa Kurikulum yang dikembangkan dengan berbasis pada kompetensi sangat diperlukan sebagai instrumen untuk mengarahkan peserta didik menjadi: 1) Manusia berkualitas yang mampu dan proaktif menjawab tantangan zaman yang selalu berubah, 2) Manusia terdidik yang beriman dan bertaqwa kepada Allah Yang Maha Esa, berakhlak mulia, sehat, berilmu, cakap, kreatif, mandiri, dan 3)Warga negara yang demokratis dan bertanggung jawab. ${ }^{94}$

Implementasi Kurikulum 2013 berbasis kompetensi dan karakter harus melibatkan semua komponen (stakeholders), termasuk komponen-komponen sistem pendidikan itu sendiri. Pendidikan karakter dalam Kurikulum 2013 diharapkan dapat meningkatkan mutu proses dan hasil pendidikan yang mengarah pada pembentukan budi pekerti dan akhlak mulia peserta didik secara utuh dan seimbang, sesuai dengan standar kompetensi pada setiap jenjang pendidikan.

b. Landasan Kurikulum 2013

Kurikulum merupakan rancangan pendidikan yang memiliki kedudukan cukup sentral dalam perkembangan pendidikan, oleh sebab itu dibutuhkan landasan yang kuat dalam pengembangan kurikulum agar pendidikan dapat menghasilkan manusia-manusia yang berkualitas. Landasan sering juga disebut dengan determinan kurikulum yaitu hal-hal yang secara mendasar menentukan kurikulum sehingga disebut juga asas-asas kurikulum. ${ }^{95}$

Adapun Landasan Kurikulum 2013 yaitu :

1) Landasan Filosofis

Landasan filosofis dalam pengembangan kurikulum menentukan kualitas peserta didik yang akan dicapai kurikulum, sumber dan isi dari kurikulum, proses

7 Kementerian Pendidikan Nasional, Strategi Pemebelajaran Pendidikan Karakter. (Bandung: Remaja Rosdakarya, 2013) 8.

${ }^{8}$ Kementerian Pendidikan dan Kebudayaan, Materi Pelatihan Guru Implementasi Kurikulum 2013 SD Kelas IV (Jakarta: Badan Pengembangan Sumber Daya Manusia Pendidikan dan Kebudayaan dan Penjminan Mutu Pendidikan, 2013), 72.

${ }^{9}$ Ali Mudlofir dan Masyhudi Ahmad, Pengembangan Kurikulum, (Surabaya: PT Revka Petra Media, 2009), 31. 
Jurnal At Tadbir STAI Darul Kamal NW Kembang kerang NTB

Volume 5 No 2 Tahun 2021

P-ISSN : 2580-3433

E-ISSN : 2715-7210

https://journal.staidk.ac.id/index.php/tadbir

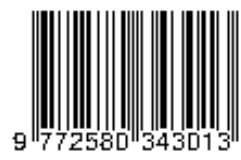

pembelajaran, posisi peserta didik, penilaian hasil belajar, hubungan peserta didik dengan masyarakat dan lingkungan alam di sekitarnya Kurikulum 2013 dikembangkan dengan landasan filosofis yang memberikan dasar bagi pengembangan seluruh potensi peserta didik menjadi manusia Indonesia berkualitas yang tercantum dalam tujuan pendidikan nasional. Pada dasarnya tidak ada satupun filosofi pendidikan yang dapat digunakan secara spesifik untuk pengembangan kurikulum yang dapat menghasilkan manusia yang berkualitas.

Berdasarkan hal tersebut, Kurikulum 2013 dikembangkan menggunakan filosofi sebagai berikut:

a) Pendidikan berakar pada budaya bangsa untuk membangun kehidupan bangsa masa kini dan masa mendatang. Pandangan ini menjadikan Kurikulum 2013 dikembangkan berdasarkan budaya bangsa Indonesia yang beragam, diarahkan untuk membangun kehidupan masa kini, dan untuk membangun dasar bagi kehidupan bangsa yang lebih baik dimasa depan.

b) Peserta didik adalah pewaris budaya bangsa yang kreatif. Menurut pandangan filosofi ini, prestasi bangsa diberbagai bidang kehidupan di masa lampau adalah sesuatu yang harus termuat dalam isi kurikulum untuk dipelajari peserta didik. Proses pendidikan adalah suatu proses yang memberi kesempatan kepada peserta didik untuk mengembangkan potensi dirinya menjadi kemampuan berpikir rasional dan kecemerlangan akademik dengan memberikan makna terhadap apa yang dilihat, didengar, dibaca, dipelajari dari warisan budaya berdasarkan makna yang ditentukan oleh budayanya dan sesuai dengan tingkat kematangan psikologis serta kematangan fisik peserta didik.

c) Pendidikan ditujukan untuk mengembangkan kecerdasan intelektual dan kecemerlangan akademik melalui pendidikan disiplin ilmu. Filosofi ini menentukan bahwa isi kurikulum adalah disiplin ilmu dan pembelajaran adalah pembelajaran disiplin ilmu (essentialism). Filosofi ini mewajibkan kurikulum memiliki nama matapelajaran yang sama dengan nama disiplin ilmu, selalu bertujuan untuk mengembangkan kemampuan intelektual dan kecemerlangan akademik.

2) Landasan Teoritis

Kurikulum 2013 dikembangkan atas teori "pendidikan berdasarkan standar" (standard-based education), dan teori kurikulum berbasis kompetensi (competencybased curriculum). Pendidikan berdasarkan standar menetapkan adanya standar nasional sebagai kualitas minimal.

Kurikulum 2013 menganut: (1) Pembelajaan yang dilakukan guru (taught curriculum) dalam proses yang dikembangkan berupa kegiatan pembelajaran di sekolah, kelas, dan masyarakat. (2) Pengalaman belajar langsung peserta didik 
Jurnal At Tadbir STAI Darul Kamal NW Kembang kerang NTB

Volume 5 No 2 Tahun 2021

P-ISSN : 2580-3433

E-ISSN : $2715-7210$

https://journal.staidk.ac.id/index.php/tadbir

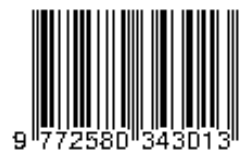

(learned-curriculum) sesuai dengan latar belakang, karakteristik, dan kemampuan awal peserta didik. Pengalaman belajar langsung peserta didik menjadi hasil belajar bagi dirinya, sedangkan hasil belajar seluruh peserta didik menjadi hasil kurikulum.

3) Landasan Yuridis

Landasan yuridis kurikulum 2013 yaitu :

a) Undang-Undang Dasar Negara Republik Indonesia Tahun 1945;

b) Undang-undang Nomor 20 Tahun 2003 tentang Sistem PendidikanNasional

c) Undang-undang Nomor 17 Tahun 2005 tentang Rencana Pembangunan Jangka Panjang Nasional, beserta segala ketentuan yang dituangkan Rencana Pembangunan Jangka Menengah Nasional dan

d) Peraturan Pemerintah Nomor 19 Tahun 2005 tentang Standar Nasional Pendidikan sebagaimana telah diubah dengan Peraturan Pemerintah Nomor 32 Tahun 2013 tentang Perubahan Atas Peraturan Pemerintah Nomor 19 Tahun 2005 tentang Standar Nasional Pendidikan. ${ }^{96}$

c. Karakteristik pembelajaran Kurikulum 2013

Dalam pembelajaran Kurikulum 2013 terdapat karakteristik yang menjadi ciri khas pembeda dengan kurikulum-kurikulum yang telah ada sebelumnya. Karakteristik Kurikulum 2013 sebagai berikut :

1) Pendekatan pembelajaran

Karakteristik pembelajaran pada setiap satuan pendidikan terkait erat pada Standar Kompetensi Lulusan dan Standar Isi. Standar Kompetensi Lulusan memberikan kerangka konseptual tentang sasaran pembelajaran yang harus dicapai. Standar isi memberikan kerangka konseptual tentang kegiatan belajar dan pembelajaran yang diturunkan dari tingkat kompetensi dan ruang lingkup materi.Kurikulum 2013 menerapkan konsep pendidikan karakter, banyak pengembangan yang dilakukan dalam kurikulum ini yaitu beban belajar, waktu belajar, pendekatan belajar dan beberapa pengembangan-pengembangan lain. Struktur Kurikulum 2013 ini salah satunya berisi tentang kompetensi inti yang menjadi patokan dalam merumuskan kompetensi dasar dan harus dicapai oleh peserta didik. Sesuai dengan Standar Kompetensi Lulusan, sasaran pembelajaran mencakup pengembangan ranah sikap, pengetahuan, dan keterampilan yang dielaborasi untuk setiap satuan pendidikan ${ }^{97}$.

Ketiga ranah kompetensi tersebut memiliki lintasan perolehan (proses psikologis) yang berbeda. Sikap diperoleh melalui aktivitas“ menerima,

\footnotetext{
${ }^{10}$ Permendikbud No 68 tahun 2013 tentang Kurikulum 2013.

${ }^{11}$ Kementerian pendidikan dan Kebudayaan, Materi Pelatihan Guru Implementasi Kurikulum $2013 \ldots, 11$.
} 
menjalankan, menghargai, menghayati, dan mengamalkan”. Pengetahuan diperoleh melalui ktivitas "mengingat, memahami, menerapkan, menganalisis, mengevaluasi, mencipta. Keterampilan diperoleh melaluiaktivitas“ mengamati, menanya, mencoba, menalar, menyaji, dan mencipta".

Pada kegiatan pembelajaran dalam Kurikulum 2013 mengunakan pendekatan saintifik yang memuat kegiatan mengamati, menanya, mengumpulkan informasi/ekperimen, mengasosiasi/menalar dan mengkomunikasikan. Adapun aktifitas saintifik ${ }^{98}$ disajikan pada tabel.

\section{Tabel 1}

\section{Tahapan Pendekatan Saintifik}

\begin{tabular}{|c|c|}
\hline Mengamati & $\begin{array}{l}\text { Siswa mencermati bacaan dan gambar yang disajikan } \\
\text { pada buku siswa. }\end{array}$ \\
\hline Menanya & $\begin{array}{l}\text { Guru menstimulus rasa ingin tau siswa dengan } \\
\text { memberikan beberapa pertanyaan, pancingan dan } \\
\text { memberikan kesempatan kepada siswa untuk } \\
\text { membuat dan merumuskan pertanyaan mereka } \\
\text { sendiri. }\end{array}$ \\
\hline $\begin{array}{l}\text { Mengumpulkan } \\
\text { Infirmasi/ekperimen }\end{array}$ & $\begin{array}{l}\text { Kegiatan mengumpulkan informasi ini bisa } \\
\text { dilakukan melalui berbagai macam kegiatan yang } \\
\text { berbeda, salah satunya dengan mencari } \\
\text { jawaban/informasi dari narasumber/responden. } \\
\text { Pada tahap ini, siswa dibimbing dan dilatih untuk }\end{array}$ \\
\hline Mengsosiasi/menalar & $\begin{array}{l}\text { mampu mencari hubungan antar pertanyaan yang } \\
\text { mereka ajukan denagn jawaban/informasi yang } \\
\text { mereka peroleh melalui kegiatan wawacara. Siswa } \\
\text { dilatih untuk mampu mengolah informasi yang } \\
\text { mereka dapatkan menjadi sebuah simpulan. }\end{array}$ \\
\hline
\end{tabular}

${ }^{12}$ Kementerian pendidikan dan Kebudayaan, Materi Pelatihan Guru Implementasi Kurikulum 2013 (Jakarta: Badan Pengembangan Sumber Daya Manusia Pendidikan dan Kebudayaan dan Penjminan Mutu Pendidikan, 2013), 100. 


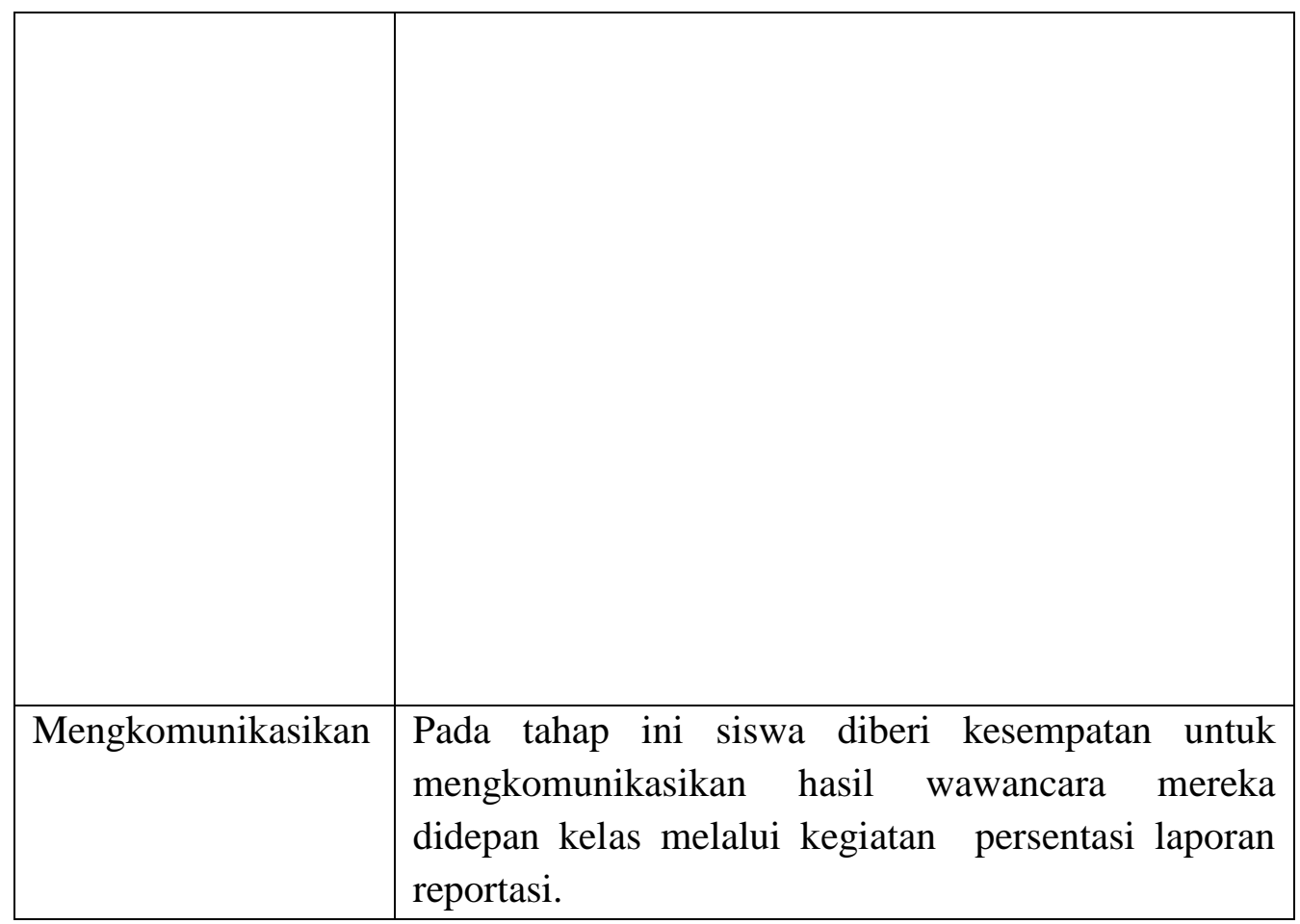

Karaktersistik kompetensi beserta perbedaan lintasan perolehan turut serta mempengaruhi karakteristik standar proses. Untuk memperkuat pendekatan ilmiah (saintifik), tematik terpadu (tematik antarmata pelajaran), dan tematik (dalam suatu mata pelajaran) perlu diterapkan pembelajaran berbasis penyingkapan/penelitian (discovery/inquiry learning). Untuk mendorong kemampuan peserta didik untuk menghasilkan karya kontekstual, baik individual maupun kelompok maka sangat disarankan menggunakan pendekatan pembelajaran yang menghasilkan karya berbasis pemecahan masalah (project based learning).

2) Kompetensi lulusan Kurikulum 2013

Menurut PP No. 32 tahun 2013 bahwa Standar Kopetensi Lulusan (SKL) adalah kriteria mengenai kualifikasi kemampuan lulusan yang mencakup sikap, pengetahuan, dan keterampilan. Kegunaan standar kopetensi lulusan adalah sebagai acuan utama dalam pengembangan Standar isi, standar proses, standar penilain pendidikan, standar pendidik dan tenaga kependidikan, standar sarana dan prasarana, standar pengolahan, dan standar pembiayaan. ${ }^{99}$

${ }^{13}$ Fadilah, Implementasi Kurikulum 2013 dalam Pembelajaran SD/MI, SMP/MTS\&SMA/MA (Yogyakarta: Ar-Ruzz Media, 2014 ), 36. 
Dalam Kurikulum 2013 standar kompetensi lulusan diterjemahkan kedalam Kopetensi Inti (KI) dan Kopetensi Dasar (KD). Dalam standar kompetensi lulusan untuk masing jenjang dibagi menjadi tiga bagian yaitu :

\section{Dimensi Sikap}

SKL yang berhubungan dengan sikap adalah memiliki perilaku yang mencerminkan sikap orang beriman, berakhlak mulia, percaya diri, dan bertanggung jawab dalam berintraksi secara evektif dengan lingkungan sosial dan alam.

\section{Dimensi Keterampilan}

SKL yang menyangkut keterampilan ialah memiliki kemampuan fikir dan tindakan yang efektif dan kreatif dalam ranah abstrak dan kongkrit sesuai yang dipelajari di sekolah.

\section{Dimensi Pengetahuan}

SKL yang berhubungkan dengan kemampuan pengetahuan ialah memiliki pengetahuan faktual, konseptual, prosedural dalam ilmu pengetahuan, teknologi, seni dan budaya, dengan wawasan kemanusiaan, kebangsaan, dan peradaban yang terkait penyebab penomena dan kejadian. ${ }^{100}$

\section{d. Komponen Implementasi Kurikulum 2013}

Implementasi dalam Kamus Besar Bahasa Indonesia memiliki arti, penerapan dan pelaksanaan. ${ }^{101}$ Adapun pengertian lain dari implemetasi adalah proses menerapkan sebuah ide atau program baru dengan harapan akan terjadi perubahan. Disamping dipandang sebagai proses, implementasi juga dipandang sebagai penerapan inovasi dan senatiasa melahirkan perubahan kearah inovasi atau perbaikan, implementasi dapat berlangsung terus-menerus sepanjang hayat. ${ }^{102}$

Merujuk pendapat diatas sesunguhnya implementasi meliputi aktivitas, kegiatan, aksi untuk mengaktualisasikan suatu ide, gagasan dari perancanan yang ada untuk mencapai tujuan tertentu.

Untuk memahami hakikat impelemntasi kurikulum maka tidak cukup hanya memahami makna implementasi itu sendiri. Oleh karna itu perlu dipaparkan sejumlah devinisi kurikulum menurut para ahli.

Pada hakikatnya kurikulum adalah seperangkat rencana dan pengaturan mengenai tujuan, isi dan bahan pelajaran serta cara yang digunakan sebagai pedoman penyelenggaraan kegiatan pembelajaran untuk mencapai tujuan pendidikan tertentu.

\footnotetext{
${ }^{14}$ Fadilah, Implementasi Kurikulum ...,38-39.

${ }^{15}$ Ananda Santoso dkk, Kamus Lengkap Bahasa Indonesia (Surabaya: Kartika Putra Pers, 2009), 199. 2006), 100.

${ }^{16}$ Syapudin Sabda, Model Kurikulum Terpadu Iptek dan Imtak (Ciputat: PT Press Grup,
} 
(UU Sisdiknas). Berangkat dari definisi itu, kurikulum tersebut setidaknya ada empat komponen penting yang ada dalam kurikulum yaitu komponen perencanaan, komponen tujuan pendidikan, komponen proses, dan komponen evaluasi. ${ }^{103}$

1). Komponen perencanaan

Perencanaan Kurikulum 2013 tidak terlepas dari pengembangan kurkulum sebelumnya, adapun model yang akan diterapkan harus memiliki landasan dan perinsisip pengembangan yang dikaji secara mendalam sehingga tidak salah tafsir terhadap pemehaman Kurikulum 2013.

Selain dimaknai sebagai suatu rancangan program, kurikulum juga dimknai sebgai proses memberikan pengalaman belajar atau materi ajar. ${ }^{104}$ Dalam konteks Kurikulum 2013 berusaha untuk lebih menanamkan nilai-nilai yang tercermin pada sikap dapat berbanding lurus dengan keterampilan pesrta didik melalui pengetahuan di bangku sekolah. ${ }^{105}$

Perencanaan disetiap mata pelajaran termasuk pelajaran akidah akhlak dituangkan dalam bentuk silabus dan RPP. Silabus dapat didefinisikan sebagai garis besar, ringkasan, ikhtisar, atau pokok-pokok isi atau materi pelajaran. Pengertian silabus yang dikeluarkan oleh Depdiknas adalah "bentuk pengembangan dan penjabaran kurikulum menjadi rencana pembelajaran atau susunan materi pembelajaran yang teratur pada mata pelajaran tertentu pada kelas/semester tertentu". ${ }^{106}$

\section{2). Komponen tujuan}

Komponen tujuan merupakan komponen pembentuk kurikulum yang berkaitan dengan hal-hal yang ingin dicapai atau hasil yang diharapkan dari kurikulum yang akan dijalankan. Dengan membuat tujuan yang pasti, hal tersebut akan membantu dalam proses pembuatan kurikulum yang sesuai dan juga membantu dalam pelaksanaan kurikulumnya agar tujuan yang diharapkan dapat tercapai, pada kurikulum 2013 adalah mengembangkan keseimbangan antara pengembangan sikap spiritual dan sosial, rasa ingin tahu, kreativitas, kerja sama dengan kemampuan intelektual dan psikomotorik.

\footnotetext{
${ }^{17}$ Ahmad Aprillah, Implementasi Kurikulum, dalam http://www.academia.edu (online) diakses pada tanggal 30. Mei , 2016 jam 14.28 Wita.

${ }^{18}$ Ahmad yani, Mindset kurikulum 2013, (Bandung: Alfebata,2014),7

${ }^{19}$ M.Fadilah, Implementasi Kuriulum 2013, „,. 16

${ }^{20}$ Nazarudin. Manajemen Pembelajaran: Implementasi Konsep, Karakteristik dan Metodologi Pendidikan Agama Islam di Sekolah Umum. (Yogyakarta: TERAS, 2007), 126.
} 


\section{3). Komponen proses (Scientific)}

Kurikulum 2013 adalah segala sesuatu yang diberikan kepada anak didik dalam kegiatan belajar mengajar dalam rangka mencapai tujuan pembelajaran dan didalamnya ada proses menanya, mengumpulkan informasi, mengasosiasi, mengkomunikasikan memerlukan rancangan pengelolaan kelas hal ini perlu sebab Kurikulum 2013 itu menggunakan Pendekatan pada Kurikulum 2013 yang berpusat pada sisiwa menngunakan pendekatan Scientific. Pendekatan ilmiah (scientific) merupakan pendekatan yang merujuk pada teknik-teknik investigasi atas fenomena atau gejala, memperoleh pengetahuan baru, atau mengoreksi dan memadukan pengetahuan sebelumnya. Untuk dapat disebut ilmiah, metode pencarian (method of inquiry) harus berbasis pada bukti-bukti dari objek yang dapat diobservasi, empiris, dan terukur dengan prinsip-prinsip penalaran yang spesifik. Karena itu, pendekatan ilmiah umumnya memuat serial aktivitas pengoleksian data melalui observasi dan ekperimen, kemudian memformulasi dan menguji hipotesis. ${ }^{107}$

Dalam proses pembelajaran berbasis pendekatan ilmiah, ranah sikap menggamit transformasi substansi atau materi ajar agar peserta didik "tahu mengapa". Hasil akhirnya adalah peningkatan dan keseimbangan antara kemampuan untuk menjadi manusia yang baik (soft skills) dan manusia yang memiliki kecakapan dan pengetahuan untuk hidup secara layak (hard skills) dari peserta didik yang meliputi aspek kompetensi sikap, pengetahuan, dan keterampilan.

Pendekatan ilmiah dalam pembelajran disajikan sebagai berikut ${ }^{108}$

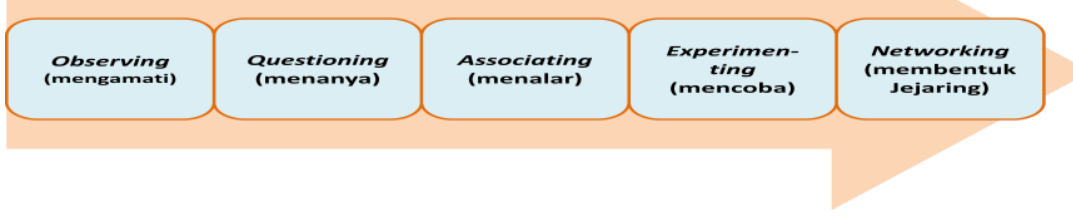

Gambar 1

Pendekatan Scientific dalam pembelajaran

a) Mengamati

Metode mengamati mengutamakan kebermaknaan proses pembelajaran (meaningfull learning). Metode ini memiliki keunggulan tertentu, seperti menyajikan media objek secara nyata, peserta didik senang dan tertantang, dan mudah pelaksanaannya. Metode mengamati sangat bermanfaat bagi pemenuhan rasa ingin tahu peserta didik. Dalam kegiatan mengamati, guru membuka secara luas dan

\footnotetext{
${ }^{21}$ Kementerian Pendidikan dan Kebudayaan, Konsep Pendekatan Scientific, 1.

${ }^{22}$ Kementerian Pendidikan..., 44.
} 
Jurnal At Tadbir STAI Darul Kamal NW Kembang kerang NTB

Volume 5 No 2 Tahun 2021

P-ISSN : 2580-3433

E-ISSN : 2715-7210

https://journal.staidk.ac.id/index.php/tadbir

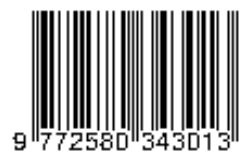

bervariasi kesempatan peserta didik untuk melakukan pengamatan melalui kegiatan: melihat, menyimak, mendengar dan membaca. Guru memfasilitasi peserta didik untuk melakukan pengamatan, melatih mereka untuk memperhatikan (melihat, membaca, mendengar) hal yang penting dari suatu benda atau obyek. ${ }^{109}$

b) Menanya

Dalam kegiatan mengamati, guru membuka kesempatan secara luas kepada peserta didik untuk bertanya mengenai apa yang sudah dilihat, disimak, dan dibaca. tentang hasil pengamatan obyek yang konkrit sampai kepada yang abstrak berkenaan dengan fakta, konsep, prosedur, ataupun hal lain yang lebih abstrak pertanyaan yang bersifat faktual sampai kepada pertanyaan yang bersifat hipotetik.

Melalui kegiatan bertanya dikembangkan rasa ingin tahu peserta didik. Semakin terlatih dalam bertanya maka rasa ingin tahu semakin dapat dikembangkan. Pertanyaan terebut menjadi dasar untuk mencari informasi yang lebih lanjut dan beragam dari sumber yang ditentukan guru sampai yang ditentukan peserta didik, dari sumber yang tunggal sampai sumber yang beragam. ${ }^{110}$

c) Menalar

Istilah "menalar" dalam kerangka proses pembelajaran dengan pendekatan ilmiah yang dianut dalam Kurikulum 2013 untuk menggambarkan bahwa guru dan peserta didik merupakan pelaku aktif. Titik tekannya tentu dalam banyak hal dan situasi peserta didik harus lebih aktif daripada guru. Penalaran adalah proses berfikir yang logis dan sistematis atas fakta-kata empiris yang dapat diobservasi untuk memperoleh simpulan berupa pengetahuan. Penalaran dimaksud merupakan penalaran ilmiah, meski penakaran nonilmiah tidak selalu tidak bermanfaat. ${ }^{111}$

d) Mencoba

Untuk memperoleh hasil belajar yang nyata atau otentik, peserta didik harus mencoba atau melakukan percobaan, terutama untuk materi atau substansi yang sesuai. Pada mata pelajaran akidah ahklak peserta didik harus memahami konsepkonsep akidah ahklak dan kaitannya dengan kehidupan sehari-hari. Peserta didikpun dibina untuk memiliki keterampilan agar dapat menerapkan dan memanfaatkan

${ }^{23}$ Peraturan Menteri Pendidikan dan Kebudayaan Republik Indonesia Nomor 81 A Tahun 2013 tentang Implementasi Kurikulum Pedoman Umum Pembelajaran, 43.

${ }^{24}$ Ibid..., 44.

${ }^{25}$ Kementerian Pendidikan dan Kebudayaan, Konsep Pendekatan Scientific, 15. 
pengetahun yang pernah diterimanya pada hal-hal atau masalah yang baru dihadapinya. ${ }^{112}$ Dengan demikian, peserta didik mampu belajar secara mandiri.

e) Membentuk Jejaring

Membentuk jejaring yang dimaksud sama dengan pembelajaran kolaboratif. Dalam pembelajaran kolaboratif ini fungsi guru hanyalah sebagai fasilitator dal artian tidak berperan aktif dalam proses pembelajaran namun sebaliknya yang lebih aktif adalah peserta didiknya. Dalam situasi kolaboratif ini peserta didik berinteraksi, saling menghormati, dan menerima kekurangan atau kelebihan peserta didik lain. Kegiatan belajarnya adalah menyampaiakn hasil pengamatan, kesimpulan berdasarkan analisis secara lisan, tertulis, atau media lainnya. Pada tahapan ini peserta didik mempresentasikan kemampuan mereka mengenai apa yang telah dipelajari sementara peserta didik lain menanggapi. Tanggapannya bisa berupa pertanyaan, sanggahan, atau dukungan tentang materi presentasi. ${ }^{113}$

\section{4). Komponen Evaluasi dan penilaian (otentik)}

Dalam kamus besar bahasa Indonesia, penilaian diartikan sebagai proses, cara, atau pembuatan nilai. Menurut Kemendikbud, penlaian adalah proses pengumpulan iformasi/bukti melalui pengukuran, menafsirkan, menddeskripsikan dan menginterprtasikan bukti-bukti hasil pengukuran. ${ }^{114}$

Penilaian dalam kurikulum dilakukan berdasar indikator-indikator pencapaian hasil belajar baik pada domain kognitif, afektif maupun psikomotor. Teknik dan instrumen penilain dalam Kurikulum 2013 dikelompokan menjadi tiga yaitu: penilaian sikap, penilaian pengetahuan dan penilaian keterampilan. ${ }^{115}$

Penilaian sikap pada jenjang MTs mencakup: penilaian sikap spiritual dan sikap sosial hal ini dapat dilihat pada tabel dibawah.

Tabel 2

Cakupan Penilaian Sikap

\begin{tabular}{|c|c|}
\hline Penilaian sikap spiritual & $\begin{array}{c}\text { Menghargai dan menghayati } \\
\text { ajaran agama yang dianut }\end{array}$
\end{tabular}

${ }^{26}$ Eveline Siregar dan Hartini Nara, Teori Belajar dan Pembelajaran (Bogor: Ghalia Indonesia, 2010), 108.

${ }^{27}$ Kementerian Pendidikan dan Kebudayaan, Konsep Pendekatan Scientific, 17.

${ }^{28}$ Fadilah, Implementasi Kurikulum ...,201

${ }^{29}$ Fadilah, Implementasi Kurikulum 2013 dalam Pembelajaran SD/MI, SMP/MTS\&SMA/MA (Yogyakarta: Ar-Ruzz Media, 2014 ), 211. 


\begin{tabular}{|c|c|}
\hline Penilaian sikap sosial & $\begin{array}{ll}\text { 1. } & \text { Jujur } \\
\text { 2. } & \text { Disiplin } \\
\text { 3. } & \text { Tanggung Jawab } \\
\text { 4. } & \text { Toleransi } \\
\text { 5. } & \text { Gotong Royong } \\
\text { 6. } & \text { Santun } \\
\text { 7. } & \text { Percaya Diri }\end{array}$ \\
\hline
\end{tabular}

Dalam pengertian terbatas, Evaluasi erat kaitannya dengan proses penilaian. Dalam penilaian otentik harus mencerminkan masalah dunia nyata, bukan dunia sekolah. Penilaian otentik tidak hanya mengukur apa yang diketahiu oleh peserta didik, tapi lebih menekankan mengukur apa yang dilakukan oleh peserta didik. ${ }^{116}$

Penilaian adalah rangkaian kegiatan untuk memperoleh, menganalisis dan menafsirkan data tentang proses dan hasil belajar peserta didik yang dilakukan secara sistematis dan berkesinambungan sehingga dapat menjadi informasi yang bermakna dalam pengambilan keputusan. Peninilaian otentik adalah penilaianyang nyata dan dibuktikan dengan kerja dan atau hasil-hasil yang telah dibuat oleh peserta didik. ${ }^{117}$

Standar penilaian Kurikulum 2013 bertujuan untuk menjamin perencanaan penilaian peserta didik sesuai dengan kompetensi yang akan dicapai dan berdasarkan prinsip-prinsip penilaian, pelaksanaan penilaian peserta didik secara profesional, terbuka, edukatif, efektif, efisien, dan sesuai dengan konteks sosial budaya; dan pelaporan hasil penilaian peserta didik secara objektif, akuntabel, dan informatif.

Penilaian autentik memiliki relevansi kuat terhadap pendekatan ilmiah dalam pembelajaran sesuai dengan tuntutan Kurikulum 2013. Penilaian ini mampu menggambarkan peningkatan hasil belajar peserta didik, baik dalam rangka mengobservasi, menalar, mencoba, dan membangun jejaring. Penilaian autentik dilakukan oleh guru dalam bentuk penilaian kelas melalui penilaian kinerja, portofolio, produk, projek, tertulis, dan penilaian diri.

Komponen evaluasi dan penilaian merupakan bagian dari pembentuk kurikulum yang berperan sebagai cara untuk mengukur atau melihat apakah tujuan yang telah dibuat itu tercapai atau tidak. Dengan begitu, kita juga dapat segera memperbaiki kesalahan yang ada atau mempertahankan bahkan meningkatkan hal-hal yang sudah baik atau berhasil.

2. Kompetensi Inti (KI) dan Kompetensi Dasar (KD) Kurikulum 2013 Madrasah Tsanawiyah.

\footnotetext{
${ }^{30} \mathrm{M}$ fadilah, Implementasi Kurikulum 2013..., 209.

${ }^{31}$ Ahmad Yani, Mindset Kurikulum 2013, (Bandung: Alvebata, 2014), 146.
} 
Standar Kompetensi mata pelajaran adalah deskripsi pengetahuan, keterampilan, dan sikap yang harus dikuasai setelah siswa mempelajari mata pelajaran tertentu pada jenjang pendidikan tertentu pula. ${ }^{118}$ _Menurut Abdul Majid Standar kompetensi merupakan kerangka yang menjelaskan dasar pengembangan program pembelajaran yang terstruktur. ${ }^{119}$

Secara konseptual dan fungsional, kompetensi inti merupakan kompetensi yang mengikat dan menaungi berbagai kompetensi dasar ke dalam aspek sikap, keterampilan, dan pengetahuan yang harus dikuasai peserta didik untuk suatu jenjang Madrasah, kelas, dan mata pelajaran. Kompetensi inti menjadi kompetensi pokok yang harus dimiliki peserta didik melalui proses pembelajaran aktif, kreatif dan inovatif serta sportif ${ }^{120}$.

Pada setiap mata pelajaran, standar kompetensi sudah ditentukan oleh para pengembang kurikulum, yang dapat kita lihat dari standar isi. Jika sekolah memandang perlu mengembangkan mata pelajaran tertentu misalnya pengembangan kurikulum muatan lokal, maka perlu dirumuskan standar kompetensinya sesuai dengan nama mata pelajaran dalam muatan lokal tersebut, ${ }^{121}$

Kompetensi Dasar adalah pengetahuan, keterampilan dan sikap minimal yang harus dicapai oleh siswa untuk menunjukkan bahwa siswa telah menguasai standar kompetensi yang telah ditetapkan, oleh karena itulah maka kompetensi dasar merupakan penjabaran dari standar kompetensi. ${ }^{122}$

Dari standar kompetensi inti, dan kompetensi dasar, dapat mengetahuai kemampuan, keterampilan dan sikap peserta didik sehingga secara spesifisik dapat dijadikan untuk menilai ketercapaian hasil pembelajaran dan juga dijadikan tolak ukur sejauh mana penguasaan siswa terhadap suatu pokok bahasan atau mata pelajaran tertentu.

3. Pembelajaran Akidah Akhlak

a. Pengertian pembeajaran akidah akhlak

Menurut Kamus Besar Bahasa Indonesia, Belajar adalah berusaha memperoleh kepandaian atau ilmu, berlatih, berubah tingkah laku atau tanggapan yang

${ }^{32}$ Wina sanjaya, Kurikulum dan Pembelajaran (Jakarta: Kencana Prenada media group, 2008), 170

${ }^{33}$ Abdul Majid, Perencanaan Pembelajaran (Bandung: PT Remaja Rosdakarya, 2012), 42 2013), 2.

34 Kemenrian Agama RI, Kurikulum Madrasah 2013 KI dan KD, (Jakarta: Grand Aquila,

${ }^{35}$ Wina Sanjaya, Kurikulum dan Pembelajaran..., 171

${ }^{36}$ Wina Sanjaya, Kurikulum dan Pembelajaran..., 171 
disebabkan oleh pengalaman. ${ }^{123}$ Belajar mengandung pengertian terjadinya perubahan dari persepsi dan perilaku, termasuk juga perbaikan perilaku. Pembelajaran adalah proses, cara, perbuatan menjadikan orang atau makhluk hidup belajar. ${ }^{124}$ sementara arti kata "Pembinaan" adalah segala usaha yang berupa kegiatan-kegiatan yang berhubungan dengan penyusunan, pelaksanaan, pengarahan, pengembangan dan pengendalian atas segala kemampuan / sifat dan pandangan hidup atas sasaran yang dituju. ${ }^{125}$ Kemudian dalam konteks akhlak, pembinaan diartikan sebagai sebuah proses pengarahan dan pengendalian yang dilakukan secara efektif dan efisien yang berkaitan dengan akhlak.

Ada dua pendekatan yang digunakan untuk mendefinisikan akidah dan akhlak, yaitu pendekatan lingustik (kebahasaan), dan pendekatan terminologik (peristilahan). ${ }^{126}$

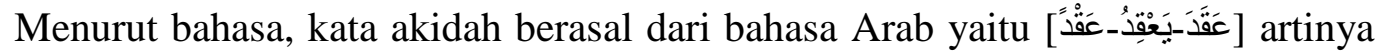
adalah mengikat atau mengadakan perjanjian. Sedangkan Akidah menurut istilah adalah urusan-urusan yang harus dibenarkan oleh hati dan diterima dengan rasa puas serta terhujam kuat dalam lubuk jiwa yang tidak dapat digoncangkan oleh badai subhat (keragu-raguan). ${ }^{127}$ Dalam definisi yang lain disebutkan bahwa akidah adalah sesuatu yang mengharapkan hati membenarkannya, yang membuat jiwa tenang tentram kepadanya dan yang menjadi kepercayaan yang bersih dari kebimbangan dan keraguan ${ }^{128}$.

Berdasarkan pengertian-pengertian di atas dapat dirumuskan bahwa akidah adalah dasar-dasar pokok kepercayaan atau keyakinan hati seorang muslim yang bersumber dari ajaran Islam yang wajib dipegangi oleh setiap muslim sebagai sumber keyakinan yang mengikat. Sementara mendefinisikan akhlak disini penulis mendatangkan beberapa pengertian dan pandangan beberapa para ahli diantaranya sebagai berikut.

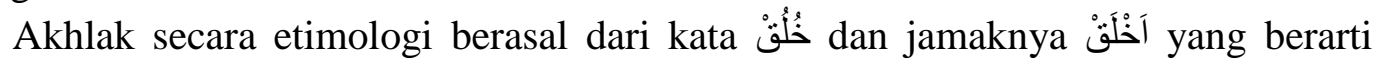
budi pekerti, etika, moral. Secara etimologi, akhlak berarti karakter dan moral

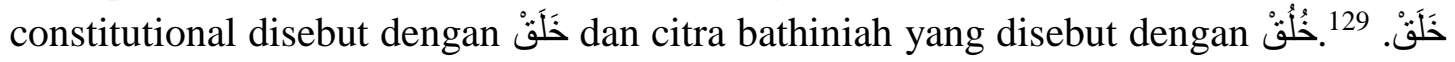

${ }^{37}$ Depdikbud, Kamus Besar Bahasa Indonesia, (Jakarta: Balai Pustaka, 1997), 50.

${ }^{38}$ Oemar Halik, Psikologi Belajar \& Mengajar..., 45.

${ }^{39}$ Depdikbud, Kamus Besar ...,117.

${ }^{40}$ Abuddin Nata, Akhlak Tasauf dan Karakter mulia (Jakarta: PT Raja Grafindo Persada, 2014), 1

${ }^{41}$ Rosihan Anwar, Akidah Akhlak (Bandung: CV Pustaka Setia, 2014), 13.

${ }^{42}$ Rosihan Anwar, Akidah Akhlak,,.. 14.

${ }^{43}$ Abu Hamid Muhammad A- Ghazali. Ihya 'Ulumu Al Din Juz III (Beirut: Dar Al Fika 2006), 58. 
merupakan citra fisik manusia, sedangkan خُلُقنْ merupakan citra psikis manusia. Berdasarkan kategori ini, maka خَلَقْ secara etimologi memiliki arti gambaran atau kondisi kejiwaan seseorang tanpa melibatkan unsur lainnya. Adapun pengertian lain dari Akhlak adalah kata yang berbentuk mufrad, jamaknya adalah khuluqun, yang berarti perangai, tabiat, adat atau khalqun yang berarti kejadian, buatan, ciptaan, moral dan karakter. ${ }^{130}$

Menurut Al-Ghazali akhlak adalah sifat yang tertanam dalam jiwa yang menimbkan macam-macam perbuatan perbuatan dengan gampang dan mudah tampa pemikiran dan pertimbangan. ${ }^{131}$ Sedangkan menurut Ibnu Maskawaih mendefinisikan خَلَقْ dengan suatu kondisi (hal) jiwa (nafs) yang menyebabkan suatu aktivitas dengan tanpa dipikirkan atau dipertimbangkan terlebih dahulu ${ }^{132}$.

Pendidikan akidah dan akhlak merupakan dua bagian yang tidak dapat dipisahkan keduanya memiliki hubungan yang sangat erat sebagaimana yang telah dipaparkan menurut para ahli ilmu. Dengan pendidikan akidah ahklak perubahan dalam tingkah laku mampu di ajarkan menuju prilaku (akhlak) yang lebih baik sesuai dengan tuntunan.

Pembelajaran Akidah Akhlak merupakan upaya sadar dan terencana dalam menyiapkan peserta didik untuk mengenal, memahami, menghayati dan mengimani Allah SWT, dan merealisasikannya dalam perilaku akhlak mulia dalam kehidupan sehari-hari melalui kegiatan bimbingan, pengajaran, latihan, penggunaan pengalaman, keteladanan dan pembiasaan, dalam kehidupan masyarakat dalam bidang keagamaan, pembelajaran itu juga diarahkan pada peneguhan akidah Islam.

Dari beberapa pengertian diatas, dapatlah penulis simpulkan bahwa pelajaran Akidah Ahlak adalah usaha yang dilakukan secara sadar dan kegiatan mengalihkan pengalaman, pengetahuan dan kecakapannya oleh pendidikan terhadap peserta didik untuk mengarahkan menjadi manusia yang beriman dan bertaqwa kepada Tuhan Yang Maha Esa, berbudi pekerti luhur dan berkepribadian yang utuh yang mengenal, memahami, menghayati, mengimani, bertaqwa dan berakhlak mulia serta mengamalkan ajaran-ajaran yang terkandung dalam Akidah dan Ahlak dalam kehidupan sehari-hari dan juga akan mengarahkan manusia dalam kehidupan yang lebih baik yang nantinya akan bermanfaat bagi dirinya sendiri dan orang lain.

b. Ruang lingkup pelajaran akidah akhlak

Adapun ruang lingkup pelajaran akidah akhlak dalam Cakupan kurikulum Pembelajaran Akidah Akhlak di Madrasah Tsanawiyah meliputi:

\footnotetext{
${ }^{44}$ Abu Hamid Muhammad A- Ghazali. Ihya 'Ulumu Al' Din ..., 59

${ }^{45}$ Zainuddin Ali, Pendidikan Agama Islam (Jakarta: Bumi Aksara, 2007), 29.

${ }^{46}$ Ibn Maskawaih. Menuju Kesempurnaan Akhlak. (Bandung: Mizan, 1994), 56.
} 
Jurnal At Tadbir STAI Darul Kamal NW Kembang kerang NTB

Volume 5 No 2 Tahun 2021

P-ISSN : 2580-3433

E-ISSN : $2715-7210$

https://journal.staidk.ac.id/index.php/tadbir

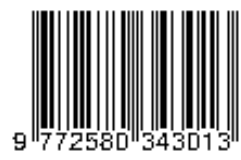

1. Aspek akidah terdiri atas keimanan kepada sifat Wajib, Mustahil dan Jaiz Allah, keimanan kepada kitab Allah, Rasul Allah, sifat-sifat dan Mu'jizat-Nya dan Hari Akhir.

2. Aspek akhlak terpuji yang terdiri atas khauf, taubat, tawadlu, ikhlas, bertauhid, inovatif, kreatif, percaya diri, tekad yang kuat, ta'aruf, ta'awun, tafahum, tasamuh, jujur, adil, amanah, menepati janji dan bermusyawarah.

3. Aspek akhlak tercela meliputi kufur, syirik, munafik, namimah dan ghibah.

Sehinga secara garis besar pembelajaran akhlak dibagi menjadi dua macam yaitu akhlak terpuji (akhlakul mahmudah) dan akhlak tercela (akhlak madzmumah). ${ }^{133}$

Adapun akhlakul mahmudah secara garis besar antara lain:

1) Akhlak yang berhubungan dengan Allah

a) Mentauhidkan Allah

Menauhidkan Allah adalah mempertegas keEsaan Allah, atau mengakui bahwa tidak ada sesuatupun yang setara dengan dzat, sifat af'al dan asma Allah SWT.

b) Takwa Kepada Allah

Kalimat "Ittaqullah" (bertakwalah kepada Allah) jika diterjemahkan secara harfiah akan menjadi 'Jauhilah Allah atau hindarkanlah dirimu dari Allah. Hal ini tentunya mustahil dapat dilakukan manusia karena siapakah yang dapat menghindarkan diri dari Allah.

c) Tawakkal

Tawakkal adalah kesungguhan hati dalam bersandar kepada Allah SWT untuk mendapatkan kemaslahatan serta mencegah kemudharatan, baik menyangkut urusan dunia maupun urusan akhirat.

2) Akhlak terhadap diri sendiri

Dalam kehidupan manusia, susah-senang, sehat-sakit, suka-duka datang silih berganti bagaikan silih bergantinya siang dan malam.Namun, kita harus ingat bahwa semua itu datang dari Allah SWT. Untuk menguji dan mengukur tingkat keimanan seorang hamba. Apakah seorang hamba itu tabah dan sabar menghadapi semua ujian itu atau tidak ?. Itu semua bergantung kepada akhlak hamba tersebut.

3) Akhlak terhadap keluarga

a) Berbakti kepada orang tua

Berbuat baik kepada orang tua merupakan ajaran yang menjadi ketetapan kitabullah Al-Qur'an dan Al-Hadits.

b) Bersikap baik kepada saudara

${ }^{48}$ Anwar Rosihan..., 215. 
Agama Islam memerintahkan agar berbuat baik kepada sanak saudara atau kaum kerabat, sesudah menunaikan kewajiban kepada Allah dan ibu bapak.

4) Akhlak terhadap masyarakat

a) Berbuat baik kepada tetangganya

Tetangga adalah orang yang terdekat dengan kita, dengan bukan karena pertalian darah atau pertalian bahkan mungkin tidak seagama dengan kita. ${ }^{134}$

b) Suka menolong orang lain

Dalam hidup ini, setiap orang pasti memerlukan pertolongan orang lain. Ada kalanya karena sengsara dalam hidup, penderitaan bathin atau kegelisahan jiwa, dan adakalanya karena sedih setelah mendapat berbagai musibah. ${ }^{135}$ Dengan demikian sebagai sesama saudara hendaklah kita saling tolong menolong dan menjunjung tinggi rasa persaudaraan serta saling menghormati dan menghargai orang lain menurut kedudukan mereka. Karena pada dasarnya kita sama-sama memiliki perasaan dan harga diri.

c. Pembinaan akhlak

Pembinan akhlak merupakan pendidikan agama Islam, dan dalam pengertian abudinata menjelaskan Pendidikan agama islam adalah usaha berupa bimbingan dan asuhan terhadap anak didik agar kelak setelah selesai pendidikannya dapat memahami dan mengamalkan ajaran agama Islam serta menjadikannya sebagai pandangan hidup (way of life) (136 $^{13}$

Hal ini dapat dipahami pembinaan akhlak Islam merupakan upaya mendasar, terencana dalam menyiapkan peserta didik untuk mengenal, memahami, menghayati hingga mengimani, bertaqwa dan berakhlak mulia dalam mengamalkan agama islam dari sumber utamanya kitab suci Al-quran dan hadist, melalui kegiatan bimbingan, pengajaran, latihan, serta penggunaan pengamalan.

4. Strategi Guru Akidah Ahklak Dalam Pembinaan akhlak Siswa dalam Kurikulum 2013 .

Sebelum diuraikan strategi guru Akidah Akhlak, terlebih dahulu dijelaskan makna strategi itu sendiri. Dalam kamus besar bahasa Indonesia strategi diartikan taktik, rencana, langkah-langkah yang dilakukan secara sistematis dalam perang. ${ }^{137}$

\footnotetext{
${ }^{49}$ Anwar Rosihan..., 115.

${ }^{50}$ Anwar Rosihan..., 155.

51 Abuddin Nata, Manajemen Pendidikan Mengatasi Kelemahan Pendidikan Islam di Indonesia, (Jakarta: Kencana Prenada Media Group, 2012), 80.

52 Ananda Santoso, Kamus Lengkap Bahasa Indonesia... , 482.
} 
Sementara dalam pengertian lain strategi adalah suatu garis besar haluan untuk bertindak dalam usaha mencapai sasaran yang telah ditentukan. ${ }^{138}$

Dalam dunia pendidikan, strategi diartikan sebagai daya upaya dalam menciptakan system lingkungan yang memungkinkan terjadinya proes belajarmengajar. ${ }^{139}$ Kem (1995) menjelas strategi pembelajaran adalah suatu kegiatan yang harus dikerjakan guru dan siswa agar tujuan pembelajaran dapat dicapai seara efektif dan efisien. ${ }^{140}$

Untuk mencapai tujuan pembelajaran maka ada beberapa startegi pembelajaran yang digunakan guru aqidak akhlak antara lain:

a) Strategi pembelajaran Inkuiri (SPI)

Strategi pembelajaran inkuiri adalah rangkaian kegiatan pembelajaran yang menekankan pada proses berfikir secara kritis dan analitis untuk mencari dan menemukan sendiri jawaban yang di pertanyakan. ${ }^{141}$ Strategi inkuiri menekankan pada aktivitas siswa secara maksimal untuk mencari dan menemukan, artinya strategi inkuiri menempatkan sisiwa sebagai subjek belajar.

Dalam proses pembelajar, siswa tidak berperan sebagai penerima pelajaran melalui penjelasan guru secara verbal, tapi mereka berperan untuk menemukan sendiri inti dari materi pelajaran itu sendiri.

b) Strategi pembelajaran kooperatif (SPK)

Pembelajaran kooperatif adalah rangkaian kegiatan belajar yang dilakukan sisiwa dalam kelompok-kelompok tertentu untuk mencapai tujuan pembelajaran yang telah dirumuskan. ${ }^{142}$ Strategi pembelajaran kooperatif merupakan model pembelajaran bentuk kelompok dan menekankan pada proses kerjasama antara siswa.

c) Strategi pembelajaran Berbasis Proyek ( Project Based Lerning)

Pembelajaran berbasis proyek (project based lerning) adalah model pembelajaran yang mengunakan proyek/kegiatan sebagai media. Peserta didik melakukan eksplorasi, penilaian, untuk menghasilkan bebrbagi bentuk hasil belajar. ${ }^{143}$ Pembelajaran berbasis proyek memiliki persamaan dengan model pembelajaran inkuiri yang menekankan pada aktivitas siswa.

${ }^{53}$ Abu Ahmadi, Strategi Belajar Mengajar (Bandung: Pustaka Setia, 2005), 12.

${ }^{54}$ Abu Ahmadi, Strategi Belajar Mengajar..., 12.

55 Wina Sajana, Strategi Pembelajaran Berorentasi standar Proes Pendidikan (Jakarta: Kencana, 2013), 216.

${ }^{56}$ Wina Sajana, Strategi Pembelajaran Berorentasi standar Proes Pendidikan ... 196.

57 Wina Sajana, Strategi Pembelajaran Berorentasi standar Proes Pendidikan ..., 240.

${ }^{58}$ Kementerian pendidikan dan Kebudayaan, Materi Pelatihan Guru Implementasi Kurikulum $2013 \ldots, 2$ 
d) Strategi pembelajaran berbasis masalah (Problem Based Lerninning)

Pembelajaran berbasis masalah (Problem Based Lerninning) merupakan sebuah pendekatan ang menyajikan masalah kontekstual sehingga merangsang peserta didik untuk belajar. Dalam kelas yang menerakan pembelajaran berbasis masalah dan merupakan sutu metode pembelajaran yang menantang peserta didik untuk "belajar bagaimana belajar," bekerjasama untuk mencari solusi dari permasalahan yang ada.

e) Strategi pembelajaran berbasis penemuan (Discovery Learning)

Discovery Learning di definisikan sebagai proses belajar yang terjadi bila pelajar tidak disajikandengan pelajaran dalam bentuk finalnya, tetapi diharapkan mengorganisasikan pembelajran sendiri. Discovery Learning mempunyai prinsip yang sama dengan inkuiri, tidak ada perbedaan yang prinsip pada kedua istilah ini, Discovery learning lebih menekankan pada ditemukanya konsep atau prinsip yang sebelumnya tidak diketahui. Perbedaanya dengan discovery ialah masalah yang dihadapkan kepada sisiwa semacam masalah yang direkayasa oleh guru. Sedangkan pada inkuiri masalahnya bukan hasil rekayasa, sehingga siswa harus mengerahkan seluruh pikiran dan keterampilan untuk mendapatkan temuan di dalam masalah yang diberikan guru. ${ }^{144}$

5. Dasar-Dasar Pendidikan Akidah Akhlak

Akhlak adalah merupakan sistem moral atau akhlak yang berdasarkan Islam, yakni bertititk tolak dari akidah yang diwahyukan Allah kepada Nabi atau Rasul-Nya yang kemudian agar disampaikan kepada umatnya. Akhlak Islam, karena merupakan sistem akhlak yang berdasarkan kepada kepercayaan kepada Tuhan, maka tentunya sesuai pula dengan dasar dari pada agama itu sendiri. Dengan demikian, dasar atau sumber pokok daripada akhlak adalah al-Qur'an dan al-Hadits (as-Sunnah) yang merupakan sumber utama dari agama itu sendiri.

Kedudukan Al-Qur'an dan Hadits sebagai sumber akhlak ditegaskan oleh Allah dalam Al-Qur'an, diantaranya QS. Al-Ahzab (33): 21 berikut.

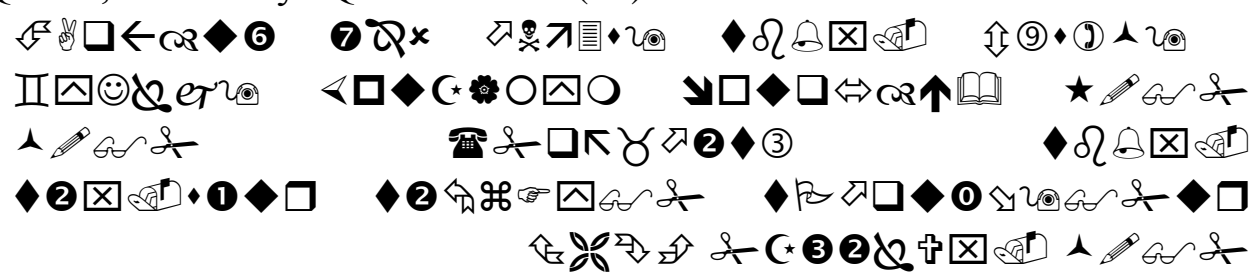

${ }^{59}$ Kementerian pendidikan dan Kebudayaan, Materi Pelatihan Guru Implementasi Kurikulum $2013 \ldots, 30$. 
Artinya: "Sesungguhnya Telah ada pada (diri) Rasulullah itu suri teladan yang baik bagimu (yaitu) bagi orang yang mengharap (rahmat) Allah dan (kedatangan) hari kiamat dan dia banyak menyebut Allah".( QS. Al-Ahzab (33): 21 ) ${ }^{145}$

Di dalam QS. Al-Qalam (68): 4, Allah SWT. Berfirman :

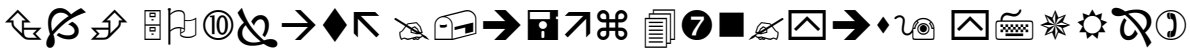

Artinya: "Dan sesungguhnya kamu benar-benar berbudi pekerti yang agung. (QS. Al-Qalam (68): 4). ${ }^{146}$

Firman Allah tersebut di atas kemudian dipertegas oleh Rasulullah Saw., melalui sabdanya Nabi Muhamad SAW yang artinya: "Aku hanya diutus untuk menyempurnakan akhlak yang mulia." Dengan landasan Al Qur'an dan Sunnah Nabi Muhammad SAW, peserta didik beriman dan bertakwa kepada Allah SWT, berakhlak mulia/berbudi pekerti luhur yang tercermin dalam perilaku sehari-hari dalam hubungannya dengan Allah, sesama manusia dan alam sekitar: mampu menjaga kemurnian akidah Islam, memiliki keimanan yang kokoh yang dilandasi dengan dalil-dalil naqli (Al Qur'an dan Hadist), dan dalil aqli, serta menjadi pelaku ajaran Islam yang baik dalam pergaulan dengan keluarga, masyarakat maupun bangsanya, dengan tetap menjaga terciptanya kerukunan hidup beragama yang dinamis sesuai dengan ajaran Islam.

6. Kendala implementasi Kurikulum 2013.

Dalam kamus ilmiah populer bahwa yang dinamakan dengan impelementasi adalah pelaksanaan. ${ }^{147}$ Sedangkan menurut Oemar Hamalik yang dinamakan dengan implementasi adalah proses penerapan ide, konsep, kebijakan, atau inovasi dalam bentuk tindakan praktis sehingga memberikan dampak. ${ }^{148}$ Dalam proses implementasi Kurikulum 2013 terdapat kendala yang ada dilapangan faktor yang mempengaruhi dintara faktor-faktor yang mempengaruhi implementasi kurikulum dapat digolongkan menjadi tiga bagian, yaitu:

\section{a. Karakteristik Kurikulum}

Karakteristik kurikulum ini mencakup ruang lingkup bahan ajar, tujuan, fungsi, sifat, dan sebagainya.

b. Strategi Implementasi

${ }^{60}$ Departemen Agama RI, Al-Qur'an dan Terjemahan (Jakarta: CV Indah Pers, 2005), 666.

${ }^{61}$ Departemen Agama Repoblik Indonesia, Al-Qur'an ..., 960

62 Ananda Santoso dkk, Kamus Lengkap ..., 245.

63 Oemar Hamalik, Dasar-dasar Pengembangan Kurikulum, (Bandung: Remaja Rosda Karya, 2007), 237. 
Strategi implementasi ini yang digunakan dalam implementasi kurikulum, seperti diskusi profesi, seminar, penataran, lokakarya penyediaan buku kurikulum, dan berbagai kegiatan lain sehingga dapat mendorong penggunan kurikulum dalam lapangan.

c. Karekteristik Pengguna Kurikulum

Kareteristik seperti ini meliputi pengetahuan, keterampilan, serta nilai-nilai dan sikap terhadap kurikulum dalam pembelajaran. Dalam mengimplementasikan kurikulum dapat melibatkan beberapa komitmen yang terlibat dan didukung oleh kemampuan profesioanal seperti guru sebagai salah satu implementor kurikulum. ${ }^{149}$

7. Faktor yang mempengaruhi akhlak

Untuk menjelaskan faktor-faktor yang mempengaruhi pembentukan akhlak pada khususnya dan pendidikan pada umumnya, ada tiga aliran yang sudah amat populer. Yaitu: aliran nativisme, aliran empirisme dan aliran behavioaris ${ }^{150}$.

\section{1) Aliran Nativisme}

Menurut aliran nativisme bahwa faktor yang paling berpengaruh terhadap pembentukan diri seseorang adalah faktor pembawaan dari dalam yang bentuknya dapat berupa kecenderungan, bakat, akal, dan lain-lain. Jika seseorang sudah memiliki kecenderungan atau pembawaan baik, maka dengan sendirinya orang tersebut akan menjadi baik. Begitu juga sebaliknya, jika seseorang memiliki kecenderungan atau pembawaan buruk, maka orang tersebut menjadi buruk. Aliran ini begitu yakin terhadap potensi dan tampak kurang menghargai peranan pendidikan dan pembinaan ${ }^{151}$.

2) Aliran Empirisme

Menurut aliran empirisme bahwa faktor yang paling berpengaruh terjadap pembentukan diri seseorang adalah faktor dari luar, yaitu lingkungan sosial, termasuk pembinaan dan pendidikan yang diberikan. Aliran ini begitu mempercayai peranan pendidikan dan pengajaran serta lingkungan yang melingkupinya. Aliran ini begitu percaya kepada peranan yang dilakukan oleh pendidikan dan pengajaran. ${ }^{152}$

2. Aliran Behavioris

${ }^{64}$ Oemar Hamalik, Dasar-dasar Pengembangan Kurikulum, (Bandung: Remaja Rosda Karya, 2007), 239.

${ }^{65}$ Abuddin Nata, Akhlak Tasawuf Dan Karanter Mulia, (Jakarta: Rajawali Pers. 2014), 143.

${ }^{66}$ Abuddin Nata, Akhlak Tasawuf..., 143

${ }^{67}$ HM Arifin Ilmu Pendidikan Islam (Jakarta: Bumi aksara, 1999)113. 
Dalam pada aliran behavioaris berpendapat "bahwa semua semua perilaku dapat dijelaskan oleh sebap-sebap lingkungan, bukan oleh kekutan internal. behavioaris berfokus pada perilaku yang dapat diamati. ${ }^{153}$

Dari beberapa lairan disebuatkan bahwa yang mempengaruhi perkebangan perilaku seseorang terbentuk oleh beberapa hal jadi tidak semata satu faktor saja yang mempengaruhi pembentukan karakter atau akhlak seorang sisiwa, berhasil dan tidaknya pembinan akhlak tergantuang mana yang paling dominan mempengaruhi pekembangan seorang anak didik.

\section{KESIMPULAN}

Dari paparan data dan pembahasan di atas, dapat disimpulkan bahwa:

1. Implementasi Kurikulum 2013 mata pelajaran akidah ahklak di Madrasah Tsanawiyah Negeri (MTs.N) Kediri.

a. Proses penerapan Kurikulum 2013 pada mata pelajaran akidah akhlak yang dilakukan guru mata pelajaran akidah akhlak mengacu pada metode bervariasi yaitu :

1) Metode ceramah. Metode ceramah masih mendominasi jalannya pembelajaran akidah akhlak, sehingga pembelajaran masih lebih berpusat pada guru.

2) Metode Diskusi. Metode ini sudah berjalan dengan baik antara murid dengan guru dan antara murid dengan murid.

3) Metode belajar kelompok, metode ini dilaksanakan dalam berbagai kegiatan pembelajaran tapi tidak terlalu sering dan metode ini dilakukan diluar dan dalam kelas

4) Metode keteladanan dan pembiasaan. Metode ini dilakukan oleh guru akidah sebagai bentuk pembiasaan akhlak terpuji dalam perilaku siswa.

b. Penilaian autentik di MTs. Negeri Kediri secara realitas sudah terlaksana. Namun, dalam proses pelaksanaan penilaian, guru masih mengalami kendala. Kurikulum 2013 guru dituntut untuk menilai keseluruhan aspek, yaitu aspek pengetahuan, sikap, dan keterampilan peserta didik.

c. Dalam evaluasi pembelajaran di MTs.N Kediri dilakukan dua tahapan yaitu jangka pendek dan jangka panjang. Evaluasi jangka pendek dilakukan setelah berlangsungnya proses belajar mengajar. Sedangkan evaluasi jangka panjang dilakukan pada tengah semester atau akhir semester.

2. Bentuk pembinaan ahklak siswa sebagai Implementasi Kurikulum 2013 di MTs.N Kediri yang dilakukan oleh guru akidah akhlak dalam kegiatan pembinaan keagamaan guna membina ahlak siswa di MTs.N Kediri untuk menujang Kurikulum

\footnotetext{
${ }^{68}$ Sudarwan Danim dan Khairil, Pisokologi pendidikan, (Bandung: Alvebata, 2014), 27.
} 
2013 pada dimensi sikap spiritual yang terkait dengan pembentukan peserta didik yang beriman dan bertakwa, dan sikap sosial yang terkait dengan pembentukan peserta didik yang berakhlak mulia, mandiri, demokratis, dan bertanggung jawab.

\section{DAFTAR PUSTAKA}

H.M. Taofik, Kreativitas Jalan Baru Pendidikan Islam, (Mataram: LEPPIMV IAIN Mataram, 2012),137.

Hassan Basri, Filsafat Pendidikan (Bandung: CV Pustaka Setia, 2014), 128.

Zainal Arifin, Pengembangan Manajmen Mutu Kurikulum Pendidikan Islam (Jogjakarta: Diva Press, 2012), 37.

Fadilah, Implementasi Kurikulum 2013 dalam Pembelajaran SD/MI, SMP/MTS\&SMA/MA (Yogyakarta: Ar-Ruzz Media, 2014 ), 16.

Mulyasa, Impelemetasi Kurikulum 2013 (Bandung: Rosdakarya, 2013), 176.

Kementerian Pendidikan Nasional, Strategi Pemebelajaran Pendidikan Karakter. (Bandung: Remaja Rosdakarya, 2013) 8.

Kementerian Pendidikan dan Kebudayaan, Materi Pelatihan Guru Implementasi Kurikulum 2013 SD Kelas IV (Jakarta: Badan Pengembangan Sumber Daya Manusia Pendidikan dan Kebudayaan dan Penjminan Mutu Pendidikan, 2013), 72.

Ali Mudlofir dan Masyhudi Ahmad, Pengembangan Kurikulum, (Surabaya: PT Revka Petra Media, 2009), 31.

Permendikbud No 68 tahun 2013 tentang Kurikulum 2013.

Kementerian pendidikan dan Kebudayaan, Materi Pelatihan Guru Implementasi Kurikulum 2013..., 11.

Fadilah, Implementasi Kurikulum 2013 dalam Pembelajaran SD/MI, SMP/MTS\&SMA/MA (Yogyakarta: Ar-Ruzz Media, 2014 ), 36.

Fadilah, Implementasi Kurikulum ...,38-39.

Ananda Santoso dkk, Kamus Lengkap Bahasa Indonesia (Surabaya: Kartika Putra Pers, 2009), 199.

Syapudin Sabda, Model Kurikulum Terpadu Iptek dan Imtak (Ciputat: PT Press Grup, 2006), 100.

Ahmad Aprillah, Implementasi Kurikulum, dalam http://www.academia.edu (online) diakses pada tanggal 30. Mei , 2016 jam 14.28 Wita.

Ahmad yani, Mindset kurikulum 2013, (Bandung: Alfebata,2014),7

M.Fadilah, Implementasi Kuriulum 2013 „,. 16 
Nazarudin. Manajemen Pembelajaran: Implementasi Konsep, Karakteristik dan Metodologi Pendidikan Agama Islam di Sekolah Umum. (Yogyakarta: TERAS, 2007), 126.

Kementerian Pendidikan dan Kebudayaan, Konsep Pendekatan Scientific, 1.

Kementerian Pendidikan..., 44.

Peraturan Menteri Pendidikan dan Kebudayaan Republik Indonesia Nomor 81 A

Tahun 2013 tentang Implementasi Kurikulum Pedoman Umum Pembelajaran, 43.

Ibid..., 44.

Kementerian Pendidikan dan Kebudayaan, Konsep Pendekatan Scientific, 15.

Eveline Siregar dan Hartini Nara, Teori Belajar dan Pembelajaran (Bogor: Ghalia Indonesia, 2010), 108.

Kementerian Pendidikan dan Kebudayaan, Konsep Pendekatan Scientific, 17.

Fadilah, Implementasi Kurikulum ...,201

Fadilah, Implementasi Kurikulum 2013 dalam Pembelajaran SD/MI, SMP/MTS\&SMA/MA (Yogyakarta: Ar-Ruzz Media, 2014 ), 211.

M fadilah, Implementasi Kurikulum 2013..., 209.

Ahmad Yani, Mindset Kurikulum 2013, (Bandung: Alvebata, 2014), 146.

Wina sanjaya, Kurikulum dan Pembelajaran (Jakarta: Kencana Prenada media group, 2008), 170

Abdul Majid, Perencanaan Pembelajaran (Bandung: PT Remaja Rosdakarya, 2012),. 42

Kemenrian Agama RI, Kurikulum Madrasah 2013 KI dan KD, (Jakarta: Grand Aquila, 2013), 2.

Wina Sanjaya, Kurikulum dan Pembelajaran ...,171

Wina sanjaya, Kurikulum dan Pembelajaran (Jakarta: Kencana Prenada media group, 2008), 170

Abdul Majid, Perencanaan Pembelajaran (Bandung: PT Remaja Rosdakarya, 2012),. 42

Kemenrian Agama RI, Kurikulum Madrasah 2013 KI dan KD, (Jakarta: Grand Aquila, 2013), 2.

Wina Sanjaya, Kurikulum dan Pembelajaran ..., 171

Wina Sanjaya, Kurikulum dan Pembelajaran ..., 171

Depdikbud, Kamus Besar Bahasa Indonesia, (Jakarta: Balai Pustaka, 1997), 50.

Oemar Halik, Psikologi Belajar \& Mengajar..., 45.

Depdikbud, Kamus Besar ...,117.

Abuddin Nata, Akhlak Tasauf dan Karakter mulia (Jakarta: PT Raja Grafindo Persada, 2014), 1.

Rosihan Anwar, Akidah Akhlak (Bandung: CV Pustaka Setia, 2014), 13.

Abu Hamid Muhammad A- Ghazali. Ihya 'Ulumu Al Din Juz III (Beirut: Dar Al Fika 2006), 58. 
Zainuddin Ali, Pendidikan Agama Islam (Jakarta: Bumi Aksara, 2007), 29.

Ibn Maskawaih. Menuju Kesempurnaan Akhlak. (Bandung: Mizan, 1994), 56.

Abuddin Nata, Manajemen Pendidikan Mengatasi Kelemahan Pendidikan Islam di Indonesia, (Jakarta: Kencana Prenada Media Group, 2012), 80.

Ananda Santoso, Kamus Lengkap Bahasa Indonesia... , 482.

Abu Ahmadi, Strategi Belajar Mengajar (Bandung: Pustaka Setia, 2005), 12.

Wina Sajana, Strategi Pembelajaran Berorentasi standar Proes Pendidikan (Jakarta: Kencana, 2013), 216.

Kementerian pendidikan dan Kebudayaan, Materi Pelatihan Guru Implementasi Kurikulum 2013..., 2

Departemen Agama RI, Al-Qur'an dan Terjemahan (Jakarta: CV Indah Pers, 2005), 666.

Departemen Agama Repoblik Indonesia, Al-Qur'an ..., 960

Oemar Hamalik, Dasar-dasar Pengembangan Kurikulum, (Bandung: Remaja Rosda Karya, 2007), 237.

Abuddin Nata, Akhlak Tasawuf Dan Karanter Mulia, (Jakarta: Rajawali Pers. 2014), 143.

HM Arifin Ilmu Pendidikan Islam (Jakarta: Bumi aksara, 1999)113.

Sudarwan Danim dan Khairil, Pisokologi pendidikan, (Bandung: Alvebata, 2014), 27 